Arq. Bras. Med. Vet. Zootec., v.63, n.2, p.333-339, 2011

\title{
Caracterização genotípica dos isolados de Escherichia coli provenientes de frangos de corte
}

\author{
[Genotypically characterization of Escherichia coli isolates from poultry] \\ I.M.M. Silva ${ }^{1,2}$, J. Evêncio-Neto ${ }^{1}$, R.M. Silva², N. Lucena-Silva ${ }^{3}$, J. Magalhães ${ }^{3}$, M. Baliza ${ }^{2}$ \\ ${ }^{1}$ Programa de Pós-Graduação em Ciência Veterinária - Universidade Federal Rural de Pernambuco \\ Rua Dom Manuel de Medeiros, S/N - Dois Irmãos \\ 50171-900 - Recife, PE \\ ${ }^{2}$ Centro de Ciências da Saúde - Universidade Federal do Recôncavo da Bahia - Santo Antônio de Jesus, BA \\ ${ }^{3}$ Instituto de Medicina Integral Professor Fernando Figueira - Recife, PE
}

\begin{abstract}
RESUMO
Caracterizaram-se genotipicamente os isolados de Escherichia coli oriundos de fígado de frangos provenientes de dois matadouros avícolas. Foram coletadas 62 amostras de fígados de frangos, sendo 30 macroscopicamente inalterados e 32 com alteração macroscópica e que originaram no descarte da carcaça. Isolaram-se 30 cepas de Escherichia coli pelo método clássico, sendo 21 isoladas de fígados inalterados e nove provenientes de carcaças rejeitadas. Utilizou-se a reação em cadeia de polimerase para verificação de genes de virulência de $E$. coli, incluindo o gene de resistência sérica (iss) para identificação de E. coli patogênica para aves, o gene para Shiga cytotoxin 1 e 2 (stx) para identificação de E. coli enteroemorrágica, o gene $b f p A$ para identificação de $E$. coli enteropatogênica e os genes para toxinas LT-I (elt) e ST-I (stI) para identificação de E. coli enterotoxigênica. Identificou-se iss em 83,3\% (25/30) dos isolados, sendo 76,2\% (16/21) provenientes de fígados de animais hígidos, e detectou-se stx em 13,3\% (4/30). Os genes stx e iss foram identificados em três fígados, caracterizando infecção mista. Os genes não foram observados em um isolado de E. coli pelo método clássico. Faz-se necessária a utilização de tecnologias para identificação e prevenção de Escherichia coli nos aviários e matadouros avícolas.
\end{abstract}

Palavras-chave: frango, Escherichia coli, caracterização genética

\begin{abstract}
The isolates of Escherichia coli from chicken livers from two slaughterhouses were genotypically characterized in 62 samples. Thirty samples were macroscopically unchanged and 32 demonstrated alterations that led to the disposal of carcass for sanitary inspection. Thirty Escherichia coli strains from 21 unchanged and 9 from carcasses that were rejected were isolated through the classical method. Polymerase Chain Reaction was performed to verify E. coli virulence of the following genes: serum resistance (iss), to identify avian pathogenic E. coli; Shiga cytotoxin 1 and 2 (stx), to identify enterohaemorrhagic E. col; bfpA, to identify enteropathogenic E. coli; LT-I (elt) and ST-I (stI) toxins to identify enterotoxigenic E. coli. Iss gene was identified in 83.3\% (25/30), being 76.2\% (16/21) from E. coli isolated strains from healthy animals. stx gene was identified in 13.3\% (4/30) of E. coli isolates, and in three of these samples was identified as stx and iss, featuring a mixed infection. The genes were not identified in one E. coli isolated from the classic method. Thus, it is necessary to use advanced technologies to identify and prevent Escherichia coli contamination in poultry farms and slaughterhouses.
\end{abstract}

Keywords: poultry, Escherichia coli; genetic characterization

Recebido em 10 de março de 2010

Aceito em 17 de março 2011

E-mail: isabellamatos@yahoo.com.br 


\section{INTRODUÇÃO}

A Escherichia coli tem comprovado papel como patógeno entérico e também extraintestinal, sendo o agente etiológico de amplo espectro de infecções invasivas no homem e nos animais, além de ser um dos integrantes da microbiota intestinal de mamíferos e aves (Ron, 2006). Com base nas características de patogenicidade, no efeito em certas culturas de células e nos grupos sorológicos, Kaper (2005) citou nove grupos de E. coli virulentos (patotipos): E. coli enteroagregativa (EaggEC), E. coli enteroemorrágica (EHEC), E. coli enteroinvasiva (EIEC), E. coli enteropatogênica (EPEC), E. coli enterotoxigênica (ETEC), E. coli que adere difusamente (DAEC), E. coli uropatogênica (UPEC), E. coli de meningite neonatal (NMEC) e E. coli patogênica para aves (APEC). Dos patotipos presentes nas aves destacam-se: a APEC e a EHEC (Rodriguez-Siek et al., 2005a; Lee et al., 2009).

A evolução de muitas bactérias ocorre por transferência horizontal de genes de outros organismos para o genoma bacteriano, facilitando a sua adaptação em novos ambientes e aumentando a sua capacidade de aquisição de fatores de virulência envolvidos em infecções (Dam e Das, 2006). Essa evolução molecular possibilita o surgimento de cepas patogênicas como ocorre nos patotipos de Escherichia coli, havendo uma relação filogenética estreita entre diversas cepas, como as cepas B e K12, não patogênicas, pela O157:H7, enteroemorrágica, e CFT073, uropatogênica (Elena et al., 2005).

Um dos mais importantes avanços na área de métodos rápidos em microbiologia foi o da tecnologia baseada na reação em cadeia da polimerase (Polimerase Chain Reaction - PCR). A técnica da PCR é um grande avanço no diagnóstico molecular de microrganismos patogênicos, como a Escherichia coli (Garcia et al., 2008).

Dentre os genes de virulência encontrados em APEC, o gene increased serum survival (iss) confere à bactéria resistência aos efeitos bactericidas do soro do hospedeiro, causando bloqueio do complexo terminal do sistema do complemento que atua na membrana celular provocando a lise da célula (Dho-Moulin e Fairbrother, 1999). Esse gene foi descrito pela primeira vez associado ao plasmídio ColV-IK94, em um isolado de E. coli proveniente de humano (Binns et al., 1979). Esse gene codifica uma lipoproteína da membrana externa da bactéria, denominada colicina. Essa proteína pode ser utilizada para estimular a produção de anticorpos monoclonais específicos para detecção de cepas virulentas de $E$. coli (Foley et al., 2003). Jonhson et al. (2008) estudaram a evolução do gene iss e detectaram a existência de três alelos nas cepas de $E$. coli (tipos I a III), sendo que o iss ocorre em múltiplas regiões do genoma. Houve a relação do referido gene com cepas de Escherichia coli oriundas de infecções extraintestinais em humanos, apesar de Kaper (2005) citar que, em humanos, a APEC está associada a infecções intra-abdominais.

A Escherichia coli enteroemorrágica (EHEC) tem a capacidade de destruir células epiteliais e produz uma citotoxina potente, a toxina Shiga (Stx), que provoca diarreia com ou sem a presença de sangue, síndrome urêmicohemolítica, e é fatal para crianças (Kaper, 2005). Existem dois grupos de Stx, denominados Stx1 e Stx2. Stx1 é muito semelhante à principal citoxina produzida pela Shigella dysenteriae sorotipo 1. Entre os membros do Stx2, há algumas diferenças (Jelacic et al., 2003).

A situação do uso indiscriminado de antimicrobianos no tratamento e prevenção de doenças é um problema de saúde animal e pública (Mota et al., 2005). Segundo Zanatta et al. (2004), 76\% das cepas de Escherichia coli de origem aviária são consideradas resistentes, assim como $77,5 \%$ são consideradas multirresistentes, e nenhuma droga foi eficiente para todas as amostras bacterianas avaliadas. Um percentual maior de cepas resistentes de $E$. coli de origem fecal foi verificado por Bogaard et al. (2001) em frangos e perus, bem como maior número de cepas multirresistentes.

Este trabalho teve o objetivo de caracterizar genotipicamente os isolados de Escherichia coli oriundos de fígados de frangos provenientes de dois matadouros avícolas do estado da Bahia.

\section{MATERIAL E MÉTODOS}

Foram colhidas 62 amostras de fígado de frango provenientes de dois matadouros avícolas do Recôncavo da Bahia, sob fiscalização do Serviço 
de Inspeção Estadual, sendo 30 fígados com aspecto macroscópico inalterado e 32 fígados com alteração macroscópica, o que originou o descarte da carcaça pela inspeção sanitária. As alterações que originaram o descarte da carcaça foram septicemia (36\%), síndrome ascítica (26\%), colibacilose (19\%), caquexia (13\%) e aerossaculite (6\%). As amostras, coletadas assepticamente, acondicionadas em recipientes estéreis, identificadas e refrigeradas, foram enviadas para análises em laboratório de microbiologia, segundo Koneman et al. (2008). Resumidamente, foi realizada a etapa de enriquecimento em caldo de infusão de cérebro coração (Brain Heart Infusion - BHI), seguida por semeadura por estrias em ágar McConkey e identificação bioquímica. Foram considerados como E. coli os cultivos que apresentaram as seguintes características: TSI (pico ácido/fundo ácido), sulfeto de hidrogênio negativo, glicose positiva com presença de gás no tubo de Durham, reação do citocromo oxidase negativa, fenilalanina desaminase negativa, indol positiva, motilidade positiva, uréase negativa, VM positiva, VP negativa e citrato negativo.

Trinta cepas de Escherichia coli foram isoladas e identificadas do fígado dos frangos pelo método microbiológico clássico, sendo 21 cepas provenientes de fígados inalterados e nove de fígados oriundos de carcaças que foram rejeitadas com suspeita de septicemia (4/9), colibacilose (3/9), síndrome ascítica (1/9) e caquexia (1/9).

Os isolados foram estocados em caldo BHI com glicerol a $15 \%$ e mantidos a $-20^{\circ} \mathrm{C}$ para posterior extração do DNA bacteriano e realização da PCR.

Para extração do DNA, $1 \mathrm{~mL}$ da suspensão da cultura bacteriana em caldo $\mathrm{BHI}$ por $24 \mathrm{~h}$ a $37^{\circ} \mathrm{C}$ foi coletado e centrifugado por $5 \mathrm{~min}$ a 13.200rpm. O sobrenadante foi descartado, e $800 \mu \mathrm{L}$ de água miliQ foram adicionados. Após homogeneização, as amostras foram submetidas a uma nova centrifugação nas mesmas condições mencionadas anteriormente. O sobrenadante foi descartado, e $80 \mu \mathrm{L}$ de água miliQ foi adicionada. Após essa etapa, as amostras foram submetidas à temperatura de $96^{\circ} \mathrm{C}$ por 10 minutos. $\mathrm{O}$ sobrenadante foi removido e mantido congelado em tubos de polipropileno a $-20^{\circ} \mathrm{C}$ até o momento da análise.

Os componentes da PCR estão descritos na Tab. 1.

Tabela 1. Componentes utilizados na realização da reação em cadeia da polimerase (PCR) para amplificação dos genes iss, stx, bfpa, elt e stl

\begin{tabular}{lcc}
\hline Componente & Volume & Concentração final \\
\hline 10X PCR buffer & $2,5 \mu \mathrm{L}$ & $1 \mathrm{X}$ \\
$10 \mathrm{mM}$ dNTP mix & $0,5 \mu \mathrm{L}$ & $0,2 \mathrm{mM}$ \\
$50 \mathrm{mM}$ MgCl2 & $0,75 \mu \mathrm{L}$ & $15 \mathrm{mM}$ \\
Taq DNA polimerase $(5 \mathrm{U} / \mu \mathrm{L})$ & $0,2 \mu \mathrm{L}$ & $2 \mathrm{U}$ \\
Água Mili-Q estéril & $16,05 \mu \mathrm{L}$ & - \\
Iniciadores $(10 \mu \mathrm{L})$ (dois primers de cada gene) & $1 \mu \mathrm{L}$ & $0,5 \mu \mathrm{L}$ \\
DNA-molde & $3 \mu \mathrm{L}$ & - \\
Total & $25 \mu \mathrm{L}$ & \\
\hline
\end{tabular}

As condições da PCR, a sequência dos primers e o tamanho do fragmento amplificado de cada gene estudado estão descritos na Tab. 2. As reações de amplificação foram realizadas em termociclador do tipo Mastercycler (Eppendorf®). Os componentes da reação foram misturados em câmara asséptica, e $22 \mu \mathrm{L}$ foram distribuídos em tubos de polipropileno de 0,2mL. Posteriormente, $3 \mu \mathrm{L}$ do lisado de cada amostra foram adicionados. Os produtos de amplificação foram separados mediante eletroforese em gel de agarose a $2 \%$, corado com brometo de etídio
$(1 \mu \mathrm{g} / \mathrm{mL})$, utilizando-se o equipamento Eletroforesis power supply EV 243 TM_Consort. Um volume de $10 \mu \mathrm{L}$ do produto amplificado foi misturado a $2 \mu \mathrm{L}$ de tampão da amostra e colocado no gel. O tempo de corrida foi de uma hora, a 100 Volts e 40mA. Em seguida, os produtos foram observados ao transluminador ultravioleta $(\mathrm{BDH} \AA)$. O padrão de tamanho molecular foi de 100pb DNA ladder. Foi realizado o controle negativo de todos os genes pesquisados. 
Silva et al.

Tabela 2. Sequência dos primers, tamanho dos fragmentos amplificados e condições usadas na PCR para deteç̧ão de genes associados à virulência

\begin{tabular}{|c|c|c|c|}
\hline $\begin{array}{l}\text { Gene/ } \\
\text { sorotipo }\end{array}$ & Sequência do primer $5^{\prime}-3^{\prime}$ & $\begin{array}{l}\text { Tamanho do } \\
\text { fragmento } \\
(\mathrm{pb})\end{array}$ & Condições da PCR \\
\hline iss/APEC & $\begin{array}{l}\text { GTG GCG AAA ACT AGT AAA ACA GC } \\
\text { CGC CTC GGG GTG GAG AA }\end{array}$ & 760 & $\begin{array}{l}5 \min 94^{\circ} \mathrm{C} / 30 \text { ciclos de } \\
1 \min 94^{\circ} \mathrm{C}, 1 \min 61^{\circ} \mathrm{C} \\
\text { e } 2 \min 72^{\circ} \mathrm{C} / 10 \min \\
72^{\circ} \mathrm{C}\end{array}$ \\
\hline stx/EHEC & $\begin{array}{l}\text { TTT ACG ATA GAC TTC TCG AC } \\
\text { CAC ATA TAA ATT ATT TCG CTC }\end{array}$ & 227 & $\begin{array}{l}5 \min 94^{\circ} \mathrm{C} / 35 \text { ciclos de } \\
1 \min 94^{\circ} \mathrm{C}, 3 \min 48^{\circ} \mathrm{C} \\
\text { e } 4 \min 72^{\circ} \mathrm{C} / 10 \min \\
72^{\circ} \mathrm{C}\end{array}$ \\
\hline bfpA/EPEC & $\begin{array}{l}\text { AAT GGT GCT TGC GCT TGC TGC } \\
\text { GCC GCT TTA TCC AAC CTG GTA }\end{array}$ & 330 & $\begin{array}{l}5 \text { min } 94^{\circ} \mathrm{C} / 29 \text { ciclos de } \\
30 \text { seg } 94^{\circ} \mathrm{C}, 1 \text { min } 56^{\circ} \mathrm{C} \\
\text { e } 2 \min 72^{\circ} \mathrm{C} / 10 \min \\
72^{\circ} \mathrm{C}\end{array}$ \\
\hline elt/ETEC & $\begin{array}{l}\text { GGC GAC AGA TTA TAC CGT GC } \\
\text { CCG AAT TCT GTT ATA TAT GTC }\end{array}$ & 696 & $\begin{array}{l}5 \text { min } 94^{\circ} \mathrm{C} / 30 \text { ciclos de } \\
1 \quad \text { min } \\
94^{\circ} \mathrm{C}(\text { desnaturação), } 1 \\
\text { min } 56^{\circ} \mathrm{C} \text { (anelamento) e } \\
1 \text { min } 72^{\circ} \mathrm{C} \text { (extensão) } \\
/ 10 \text { min } 72^{\circ} \mathrm{C}\end{array}$ \\
\hline stI/ETEC & $\begin{array}{l}\text { TTA ATA GCA CCC GGT ACA AGC AGG } \\
\text { CTT GAC TCT TCA AAA GAG AAA ATT } \\
\text { AC }\end{array}$ & 147 & $\begin{array}{l}5 \min 94^{\circ} \mathrm{C} / 30 \text { ciclos de } \\
1 \min 94^{\circ} \mathrm{C}, 1 \min 55^{\circ} \mathrm{C} \\
\text { e } 1 \min 72^{\circ} \mathrm{C} / 10 \min \\
72^{\circ} \mathrm{C}\end{array}$ \\
\hline
\end{tabular}

\section{RESULTADOS E DISCUSSÃO}

O gene iss foi identificado em $83,3 \%$ (25/30) das amostras (Fig. 1). Os resultados são semelhantes aos verificados por Rocha et al. (2008), que detectaram iss em $73,8 \%(45 / 61)$ dos isolados, assim como os $81,5 \%$ antes encontrados por Rodriguez-Siek et al. (2005a), 82,7\% diagnosticados por Ewers et al. (2004) e $77 \%$ reportados por Pfaff-Pfaff-McDonough et al. (2000). Barnes et al. (2008) ressaltaram que a APEC representa um sério problema para a avicultura, devido aos grandes prejuízos econômicos causados por quadros como: pneumonia, peritonite, coliseptsemia, celulite, pleuropneumonia, peri-hepatite, pericardite, salpingite, panolfalmia, osteomielite/sinovite, onfalite, coligranuloma, síndrome de cabeça inchada e doença crônica respiratória.

Entre os genes de iss identificados, $76,2 \%$ (16/21) foram provenientes de amostras de $E$. coli isoladas de fígados oriundos de animais hígidos. Kawano et al. (2006) encontraram dados similares, detectando iss em $63,3 \%$ das amostras de E. coli originárias de aves aparentemente saudáveis, no Japão. Um percentual menor foi observado por McPeake et al. (2005), 17,8\%, apesar de terem identificado iss em $72,8 \%$ das amostras de E. coli isoladas de aves com septicemia. Gonçalves (2005) analisou 120 frangos aparentemente sadios por meio de amostras de suabes oriundas de traqueia e sacos aéreos e encontrou E. coli em 118 frangos, porém a deteç̧ão do gene iss só ocorreu em $10,2 \%$ das amostras (12/118). Rodriguez-Siek et al. (2005b) detectaram o gene iss em $18,3 \%$ nas aves aparentemente saudáveis e $82,7 \%$ nas aves com colibacilose. Nesse último estudo, os autores relataram que o gene iss esteve mais associado a infecções sistêmicas, incluindo o isolamento em amostras de fígado, coração, baço ou sangue (86,5\%). Encontraram também prevalência desse gene em frangos (84,9\%) e em perus $(76,2 \%)$ e verificaram que ele estava relacionado com os sorogrupos O78 (95,5\%), O2 (86\%) e O1 (66,7\%). A identificação do gene iss, o qual está relacionado à APEC, em animais aparentemente sadios, indica que os animais aparentemente sadios e infectados com a Escherichia coli patogênica para aves não são isolados/descartados nos aviários e, ao atingirem 


\section{Caracterização genotípica...}

a idade de abate, são encaminhados ao matadouro avícola para posterior consumo humano. Saliente-se que, segundo Kaper (2005), a APEC é uma zoonose e está associada a infecções intra-abdominais em humanos.

O gene stx foi identificado em 13,3\% (4/30) dos isolados de E. coli (Fig. 2). Observou-se associação entre stx e iss em três amostras, caracterizando uma infecção mista. Resultados semelhantes foram verificados por Lee et al.
(2009), que analisaram 39 isolados de E. coli provenientes de carnes bovina, suína e de frango, por meio de PCR multiplex, os quais encontraram 7,3\% de amostras de carne de frango identificadas como EHEC. Jelacic et al. (2003) analisaram 82 amostras de EHEC oriundas de humanos e verificaram que $100 \%$ continham os genes do grupo stx2, e $84 \%$ do stx1, demonstrando que o sorotipo EHEC é mais prevalente em humanos do que em frangos.

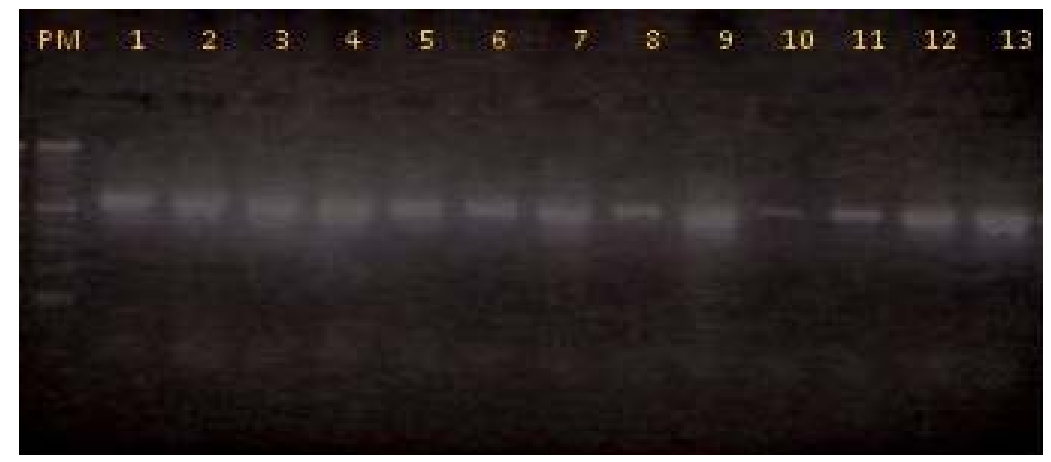

Figura 1. Fotografia do gel de agarose a $2 \%$ da PCR para gene iss das amostras de $E$. coli isoladas de fígados de frangos. Tamanho do fragmento 760pb, PM Peso Molecular 100pb, amostras positivas 1-13.

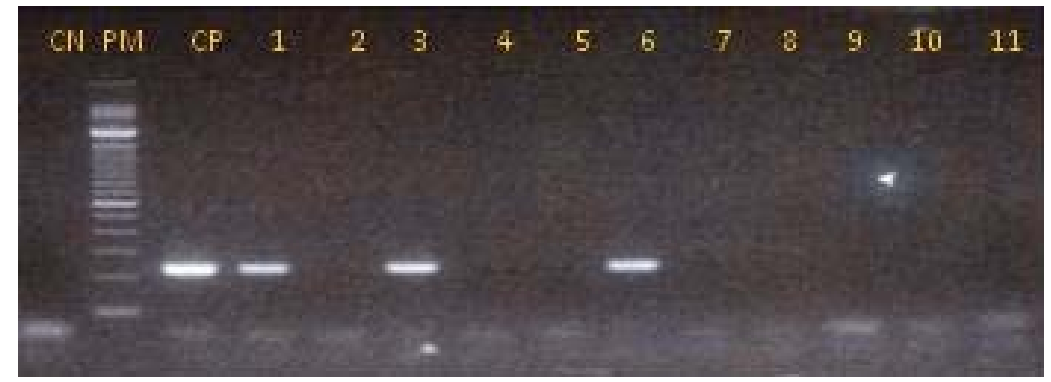

Figura 2. Fotografia do gel de agarose a $2 \%$ da PCR para gene stx das amostras de $E$. coli isoladas de fígados de frangos. Tamanho do fragmento 227pb, CN controle negativo, PM Peso Molecular 100pb, CP controle positivo, amostras positivas 1,3 e 6 .

Não foram identificados os genes $b f p A$, elt e stI nas cepas analisadas, e, como tal, não houve a caracterização genética de EPEC e ETEC. Baixa prevalência do gene $b f p A$, também foi verificada por Krause et al. (2005), os quais examinaram a presença da intimina em diversos animais por meio do gene $b f p A$, que estava presente em 2,3\% das amostras de frangos. Percentual mais elevado foi encontrado em humanos por Blanco et al. (2006), que estudaram amostras de EPEC isoladas de crianças com diarreia, ou seja 40,5\% possuíam os genes eae e $b f p A$. Wang (2008) constatou genes para enterotoxina termolábil (lt) de ETEC em 2,5\% dos isolados de E. coli provenientes de frangos, e Ahmadi et al. (2009) não detectaram ETEC por meio de genes para identificação de enterotoxina termoestável (st) nas 25 amostras de frangos analisadas. Nagy e Fekete (2005) ressaltaram que a ETEC é o tipo mais comum de colibacilose em animais jovens, porém ocorre principalmente em suínos e bovinos, sendo responsável pela diarreia dos viajantes e crianças em países em desenvolvimento. 
Os genes utilizados neste estudo não foram identificados em apenas uma amostra de E. coli isolada pelo método microbiológico clássico. Saliente-se que o isolado pode pertencer a outro sorotipo, ser um dos sorotipos e não possuir os genes pesquisados, ou ter sofrido mutação. Por conseguinte, faz-se necessária a utilização de novas tecnologias para identificação e prevenção da Escherichia coli patogênica nos aviários e matadouros avícolas, especialmente APEC, considerando-se a eficácia questionável dos antimicrobianos, administrados em doses subterapêuticas ou terapêuticas, e os prejuízos do seu uso indiscriminado, como também as limitações do diagnóstico preciso por meio das características macroscópicas observadas nas linhas de inspeção do frango na indústria.

\section{AGRADECIMENTOS}

À CAPES e à Universidade Federal do Recôncavo da Bahia, pelo fomento da bolsa. Ao Centro de Ciências da Saúde da Universidade Federal do Recôncavo da Bahia e ao Laboratório de Biologia Molecular do Serviço de Oncologia Pediátrica do Instituto de Medicina Integral Professor Fernando Figueira, por disponibilizar as instalações. À Agência de Defesa Agropecuária da Bahia e matadouros avícolas, pelo uso das instalações e doação dos fígados.

\section{REFERÊNCIAS BIBLIOGRÁFICAS}

AHMADI, M.; MARDANI, K.; AIREMLOU, N. et al. Detection of LT and ST genes in Escherichia coli isolated from dogs, sheep and poultry. Comp. Clin. Pathol., v.18, p.407-412, 2009.

BARNES, H.J.; VAILLANCOURT, J.P.; GROSS, W.B. Colibacillosis. In: SAIF, Y.M. (Ed.). Diseases of poultry. 12.ed. Ames, Iowa: Iowa State University, 2008. p.631-656.

BINNS, M.M.; DAVIES, D.L.; HARDY, K.G. Cloned fragments of the plasmid CoIV-I-K94 specifying virulence and serum resistance. Nature, v.279, p.778781, 1979.

BLANCO, M.; BLANCO, J.; DAHBI, G. et al. Typing of intimin (eae) genes from enteropathogenic Escherichia coli (EPEC) isolated from children with diarrhoea in Montevideo, Uruguay: identification of two novel intimin variants ( $\mu \mathrm{B}$ and $\xi \mathrm{R} / \beta 2 \mathrm{~B}$ ). J. Med. Microbiol., v.55, p.1165-1174, 2006.
BOGAARD, A.E.V.D.; LONDON, N.; DRIESSEN, C. et al. Antibiotic resistance of faecal Escherichia coli in poultry, poultry farmers e poultry slaughters. $J$. Antimicrob. Chemother., v.47, p.763-771, 2001.

DAM, T.; DAS, P. Plasmids - potential tool for the investigation of gene transfer $\mathrm{n}$ Mycobacterium tuberculosis. J. Med. Microbiol., v.55, p.479-480, 2006.

DHO-MOULIN, M.; FAIRBROTHER, J.M. Avian pathogenic Escherichia coli (APEC). Vet. Res., v.30, p.299-316, 1999.

ELENA, S.F.; WHITTAM, T.S.; WINKWORTH, C.L. et al. Genomic divergence of Escherichia coli strains: evidence for horizontal transfer and variation in mutation rates. Int. Microbiol., v.8, p.271-278, 2005.

EWERS, C.; JANBEN, T.; KIEBLING, S. et al. Molecular epidemiology of avian pathogenic Escherichia coli (APEC) isolated from colisepticemia in poultry. Vet. Microbiol., v.104, p.91-101, 2004.

FOLEY, S.L.; HORNE, S.M.; GIDDINGS, C.W. et al. Monoclonal antibodies to avian Escherichia coli Iss. Avian Dis., v.47, p.79-86, 2003.

GARCIA, P.M.; ARCURI, E.F.; BRITO, M.A.V.P. et al. Detecção de Escherichia coli O157:H7 inoculada experimentalmente em amostras de leite cru por método convencional e PCR multiplex. Arq. Bras. Med. Vet. Zootec., v.60, p.1241-1249, 2008.

GONÇALVES, P.M.R. Escherichia coli com detecção do gene iss por PCR, Micoplasmas e Salmonelas na qualidade sanitária de frangos de corte ao abate. 2005. 84f. Tese (Doutorado em Medicina Veterinária, área de Higiene Veterinária e Processamento Tecnológico de Produtos de Origem Animal) Universidade Federal Fluminense, Rio de Janeiro.

JELACIC, J.K.; DAMROW, T.; CHEN, G.S. et al. Shiga Toxin-Producing Escherichia coli in Montana: Bacterial genotypes and clinical profiles. J. Infect. Dis., v.188, p.719-729, 2003.

JOHNSON, T.J.; SKYBERG, J.; NOLAN, L.K. Multiple antimicrobial resistance region of a putative virulence plasmid from Escherichia coli isolate incriminated in avian colibacillosis. Avian Dis., v. 48, p. 351-360, 2004.

JOHNSON, T.J.; WANNEMUEHLER, Y.M.; NOLAN, L.K. Evolution of the iss gene in Escherichia coli. Appl. Environ. Microbiol., v.74, p.2360-2369, 2008.

KAPER, J.B. Pathogenic Escherichia coli. Int. J. Med. Microbiol., v.295, p.355-356, 2005. 
KAWANO, M.; YAGUCHI, K.; OSAWA, R. Genotypic analyses of Escherichia coli isolated from chickens with colibacillosis and apparently healthy chickens in Japan. Microbiol. Immunol., v.50, p.961966, 2006.

KONEMAN, E.W.; ALLEN, S.D.; JANDA, W.M. et al. Diagnóstico microbiológico-texto e atlas colorido. 6.ed. Rio de Janeiro: Guanabara Koogan, 2008. 1760p.

KRAUSE, G.; ZIMMERMANN, S.; BEUTIN, L. Investigation of domestic animals and pets as a reservoir for intimin- (eae) gene positive Escherichia coli types. Vet. Microbiol., v.106, p.87-95, 2005.

LEE, G.Y.; JANG, H.I.; HWANG, I.G. et al. Prevalence and classification of pathogenic Escherichia coli isolated from fresh beef, poultry, and pork in Korea. Int. J. Food Microbiol., v.134, p.196200, 2009.

McPEAKE, S.J.W.; SMITH, J.A.; BALL, H.J. Characterisation of avian pathogenic Escherichia coli (APEC) associated with colisepticaemia compared to faecal isolates from healthy birds. Vet. Microbiol., v.110, p.245-253, 2005.

MOTA, R.A.; SILVA, K.P.C.; FREITAS, M.F.L. et al. Utilização indiscriminada de antimicrobianos e sua contribuição à multirresistência bacteriana. Braz. J. Vet. Res. Anim. Sci., v.42, p.465-470, 2005.

NAGY, B.; FEKETE, P.Z. Enterotoxigenic Escherichia coli in veterinary medicine. Int. J. Med. Med., v.295, p.443-454, 2005.
PFAFF-McDONOUGH, S.J.; HOME, S.M.; GIDDINGS, C.W. et al. Complement resistancerelated traits among Escherichia coli isolates from apparently health birds and birds with colibacillosis. Avian Dis., v.44, p.23-33, 2000.

ROCHA, A.C.G.P.; ROCHA, S.L.S.; LIMA-ROSA, C.A.V. et al. Genes associated with patogenicity of avian Escherichia coli (APEC) isolated from respiratory cases of poultry. Pesqui. Vet. Bras, v.28, p.183-186, 2008.

RODRIGUEZ-SIEK, K.E.; GIDDINGS, C.W.; DOETKOTT, C. et al. Comparison of Escherichia coli isolates implicated in human urinary tract infection and avian colibacillosis. Microbiology, v.151, p.20972110, 2005a.

RODRIGUEZ-SIEK, K.E.; GIDDINGS， C.W.; DOETKOTT, C. et al. Characterizing the APEC pathotype. Vet. Res., v.36, p.241-256, 2005 b.

RON, E.Z. Host apecificity of septicemic Escherichia coli: human and avian pathogens. Curr. Opinion Microbiol., v.9, p.28-32, 2006.

WANG, S.J. Rapid and specific detection of Enterotoxigenic Escherichia coli and Salmonella strains by Multiplex PCR Systems. J. Food Drug Anal., v.16, p.81-87, 2008.

ZANATTA, G.F.; KANASHIRO, A.M.I.; CASTRO, A.G.M. et al. Suscetibilidade de amostras de Escherichia coli de origem aviária a antimicrobianos. Arq. Inst. Biol., v.71, p.283-286, 2004. 